\title{
Strategi Ketahanan Pangan Beras berdasarkan Pendekatan Food Miles
}

\author{
Armandha Redo Pratama, Sudrajat, Rika Harini, Purna Hindayani
}

Masuk: 21072021 / Diterima: 23112021 / Dipublikasi: 01122021

\begin{abstract}
Indonesia is one of the largest archipelagic countries in the world. The water area is wider than the land area. This condition causes the distribution factor to become a priority to achieve rice security throughout Indonesia. Rice distribution activities in archipelagic countries have their challenges, so a special strategy is needed based on the region's characteristics to achieve rice security. Based on the data analysis, it can be classified based on the availability and demand for rice and the distance traveled to fulfill the rice. As a result, there are six different categories. Based on the analysis using a linear transportation program and the SWOT method, it can be seen that each category has a different strategy, namely distributive, defensive, protective, revolutionary, progressive, and varied strategies. This study is expected to be one of the studies that can recommend rice food security policies from the distribution aspect.
\end{abstract}

Key words: Food Miles; Surplus; Deficit; Distribution of Rice; Strategy

Abstrak Indonesia merupakan salah satu negara kepulauan terbesar di dunia. Luas wilayah perairannya lebih luas dibandingkan dengan daratannya. Kondisi ini mengakibatkan faktor distribusi menjadi hal prioritas untuk dapat mencapai ketahanan beras di seluruh wilayah Indonesia. Kegiatan distribusi beras di negara kepulauan memiliki tantangan tersendiri, sehingga diperlukan strategi khusus berdasarkan karakteristik wilayahnya untuk mencapai ketahanan beras. Berdasarkan analisis data dapat diklasifikasikan wilayah berdasarkan ketersediaan dan kebutuhan beras, serta jarak tempuh pemenuhan berasnya. Berdasarkan analisis menggunakan metode transportasi linier programing dan SWOT dapat diperoleh hasil masingmasing kategori tersebut memiliki strategi yang berbeda, yaitu strategi distributif, defensif, protektif, revolutif, progresif dan variatif. Kajian ini diharapkan mampu menjadi salah satu kajian yang dapat menjadi rekomendasi dalam menentukan kebijakan ketahanan pangan beras dari aspek distribusi.

Kata kunci: Food Miles; Surplus; Defisit; Distribusi Beras; Strategi

This is an open access article under the CC BY-SA license.

Copyright () 2021 by Author. Published by Universitas Pendidikan Ganesha.

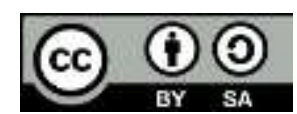

\section{Pendahuluan}

Negara Indonesia merupakan negara kepulauan yang luas dengan jumlah provinsi sebanyak 34 provinsi. Indonesia merupakan salah satu negara kepulauan terbesar di dunia. Luas perairan yang dimiliki lebih luas

Armandha Redo Pratama ${ }^{1}$, Sudrajat ${ }^{2}$, Rika Harini², Purna Hindayani $^{1}$

${ }^{1}$ Universitas Pendidikan Indonesia, Indonesia

2Universitas Gadjah Mada, Indonesia

armandharedo@upi.edu dibandingkan dengan luas daratannya (Verstappen, 2013). Wilayah Indonesia yang luas, kemudian didukung oleh kondisi iklim tropis menjadikan Indonesia kaya akan potensi sumberdaya bidang pertanian, termasuk sumberdaya pangan.

Penelitian

sebelumnya menyebutkan bahwa potensi sumberdaya pangan yang melimpah ini masih belum dapat menjadikan Indonesia sebagai negara yang dapat 
memenuhi kondisi ketahanan pangan nasional secara maksimal. (Sulaiman, 2019; Suratha, 2017; Suryana, 2014)

Ketahanan pangan memiliki beberapa aspek dimensi, diantaranya ialah food availability, food access, utilization dan stability. (Brief F.P, 2006; Lawlis et al., 2018; Lin \& He, 2020). Keempat indikator tersebut menggambarkan sistem yang terdiri atas penawaran, permintaan, distribusi, pemanfaatan serta usaha menjaga stabilitas harga dari komoditas pangan.

Indonesia merupakan salah satu negara kepulauan terbesar di dunia. (Pramono \& Changming, 2019). Hal ini tantangan tersendiri dalam hal penyaluran logistik, tidak hanya terbatas pada kondisi akses wilayah, tertapi juga sosial budaya masyarakat setempat. (Herdiawan, 2015). (World Bank, 2019) menyebutkan bahwa terdapat beberapa prioritas kebijakan terkait ketahanan pangan yang direkomendasikan untuk Indonesia, rekomendasi tersebut antara lain mengubah penekanan belanja negara bagi pertanian, dan penanganan masalah akses dan keberlanjutan penggunaan tanah dan sumberdaya alam.

Berdasarkan penjelasan
tersebut, maka untuk mencapai
ketahanan pangan beras di Indonesia, faktor aksesibilitas menjadi faktor yang harus diperhatikan untuk menjamin ketersediaan beras masing-masing provinsi. (Brief F.P, 2006) juga menyebutkan bahwa indikator akses terhadap pangan dapat diwujudkan dengan pemerataan pangan beras kepada seluruh masyaratkat.

Dalam laporan tahunan Perum Bulog tahun 2016 dilaporkan bahwa aksesibilitas pangan menjadi salah satu perhatian khusus bagi Perum Bulog di Indonesia, hal ini bertujuan untu efisiensi biaya distribusi. Hal ini sesuai dengan pendapat (Edward Frazelle, 2002) menyebutkan bahwa dalam pelaksanaan aktivitas logistik, transportasi biasanya menghabiskan $46,5 \%$ - 58,6\% dari keseluruhan biaya logistik. Secara umum biaya transportasi ini dapat ditekan dengan mengatur sistem transportasi yang ideal, sehingga efisiensi biaya distribusi dapat dapat berperan dalam menjaga indeks harga beras tetap stabil di seluruh wilayah Indonesia.

Badan pusat statistik Indonesia (BPS) mencatat bahwa sebagian provinsi di Indonesia memenuhi pasokan beras di daerahnya dengan mendatangkan beras dari daerah yang lebih jauh, sebagai contoh ialah Provinsi Sumatera Utara yang mendatangkan sebanyak 12,7\% kebutuhan beras di daerahnya dari Provinsi Sulawesi Selatan (Badan Pusat Statistik, 2016). Mendatangkan beras dari wilayah yang sangat jauh, tentu akan mengakibatkan biaya produksi menjadi lebih besar, sehingga harga beras akan mengikuti rasio dari biaya produksi. Pendekaan jarak tempuh dalam distribusi pangan ini disebut food miles. (Cushing, 2020; Lopez \& Khanal, 2020; Wong, 2019)

(Kemp et al., 2010) menyebutkan bahwa pada dasarnya pendekatan food miles memiliki tiga indikator, yaitu aksesibilitas, biaya dan lingkungan. Ketiga indikator tersebut saling terkait, dimana semakin sulit akses makanan yang diperoleh, maka biaya yang dikeluarkan akan semakin besar, selain itu dampak lingkungan yang diberikan juga semakin besar. Hal ini akibat emisi gas kendaraan yang digunakan dalam 
proses distribusi. Selain itu (Nashwari, 2020) juga menyebutkan bahwa permasalahan terkait penyediaan data dalam penyusunan kebijakan distribusi pangan menjadi prioritas I yang harus ditangani. Hal ini dapat dilihat pada tabel 1.

Tabel 1. Prioritas Masalah pangan

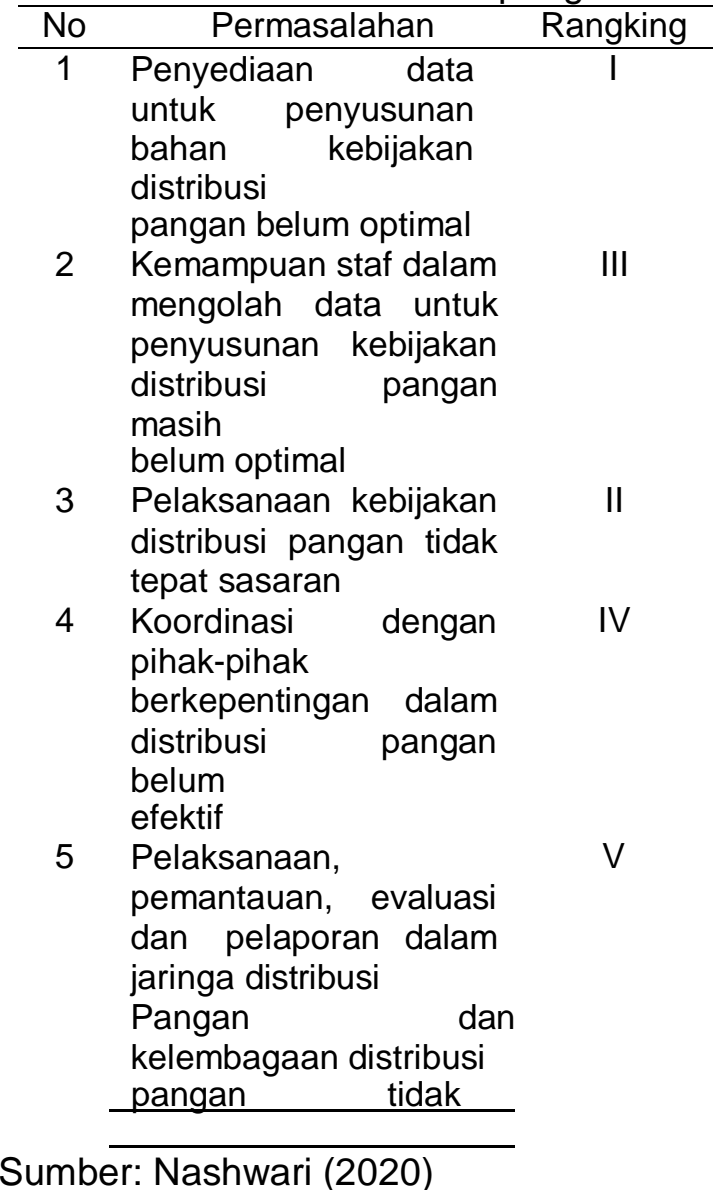

Gambaran umum yang telah dijabarkan sebelumnya menunjukan bahwa ketahanan pangan tidak hanya terfokus pada aspek konsumsi dan produksi saja, tetapi juga meliputi aspek distribusi. Penelitian ini lebih memfokuskan kepada dimensi distribusi dalam usaha keterjangkauan akses pangan khususnya beras bagi warga Indonesia. Analsis dengan menggunakan pendekatan food miles, serta pendekatan keruangan geografis diharapkan dapat memberikan solusi dan strategi yang tepat dalam upaya ketahanan pangan nasional dalam hal ini berupa komoditas beras.

\section{Metode}

Penelitian ini merupakan penelitian kuantitatif berdasarkan data sekunder yang diperoleh dari lembaga pemerintah yang berwenang. Data tersebut kemudian dianalisis dengan menggunakan metode transportasi linier programing dan kemudian dideskripsikan menggunakan grafik, tabel maupun data spasial berupa peta.

Pengumpulan data sekunder dilakukan dengan menginventarisasi dokumen-dokumen dari Badan Pusat Statistik, seperti statistik pertanian Indonesia Statistik Indonesia tahun 2019. Secara umum model matematika linier program dapat dinyatakan sebagai berikut.

1) Fungsi Tujuan

Minimumkan Biaya Angkutan:

$\sum_{i=1}^{m} \cdot \sum_{i=1}^{n} C i j X i j$

2) Fungsi Kendala

a. Kendala Pengadaan: $\sum_{i=1}^{n} X i j \leq S i$

b. Kendala Permintaan: $\sum_{i=1}^{n} X i j=D i$.

Keterangan:

$\mathrm{Si}=$ Jumlah pengadaan beras pada divisi regional (divre) ke-i (Ton).

$D j=$ Permintaan beras Provinsi ke-j (Ton).

$\mathrm{Cij}=$ Ongkos angkut dari divisi regional (divre) (i) ke Provinsi tujuan j (Rp/Ton).

Sumber: Karo (2016)

Tahap-tahap yang dilakukan dalam pengolahan data untuk analisis 
optimasi distribusi beras di Indonesia ialah analisis metode transportasi, analisis sampling data, menyelesaikan masalah transportasi dengan linier programing dan software LINDO 6.1, menentukan solusi optimal, membuat kesimpulan dan memetakan jalur distribusi beras di Indonesia berdasarkan biaya optimum. Selanjutnya ialah merumuskan strategi ketahanan pangan beras berdasarkan pendekatan food miles menggunakan analisis SWOT.

\section{Hasil dan Pembahasan Distribusi Perdagangan Beras}

Indonesia merupakan negara agraris, dimana hampir di setiap provinsi memiliki sawah dan memproduksi beras sebagai makanan pokok. Namun ternyata, persentase pembelian beras yang berasal dari dalam provinsi di Indonesia cenderung menurun tiap tahunnya. Kondisi ini tentu menjadi salah satu indikasi belum efisienya usaha distribusi beras dalam rangka mancapai ketahanan pangan di Indonesia, sebab pembelian beras dari jarak yang lebih jauh cenderung meningkat. Tren persentase pemenuhan beras dapat dilihat pada Gambar 1.

Setelah mengetahui tren pembelian beras dalam provinsi, selanjutnya ialah menganalisis bagaimana distribusi perdagangan beras yang terjadi pada masing-masing provinsi selama tahun 2018. Hasilnya dapat disimpulkan bahwa terdapat tiga kategori distribusi beras berdasarkan food miles, yaitu distribusi jauh, sedang, dan dekat.

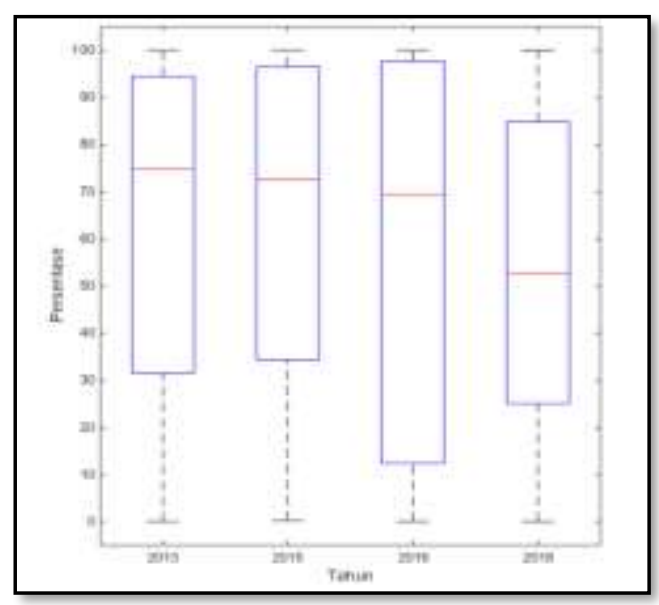

Gambar 1. Tren persentase pemenuhan beras berasal dari dalam provinsi

Sumber: Pratama (2019)

Provinsi yang melakukan kegiatan distribusi perdagangan beras paling jauh sebagian besar berada pada Indonesia bagian timur. Contohnya ialah Provinsi Maluku Utara yang merupakan provinsi dengan jarak distribusi perdagangan beras terpanjang, yaitu sepanjang $14.697 \mathrm{Km}$. Total jarak ini membuat Provinsi Maluku Utara termasuk dalam kategori Jauh dalam hal jarak pemenuhan kebutuhan beras. Provinsi lainnya yang termasuk dalam kategori jauh ialah Riau, Kepulauan Bangka Belitung, Kalimantan Barat, Kalimantan Utara, Sulawesi Utara, Papua, dan Papua Barat. Selanjutnya ialah Provinsi dengan jarak pemenuhan kebutuhan beras kategori sedang ialah Jambi, Kepulauan Riau, Nusa Tenggara Timur, Kalimantan Tengah, Kalimantan Selatan, Sulawesi Selatan, Gorontalo, dan Maluku. Kategori terakhir ialah Pola Distribusi Perdagangan Beras provinsi yang memiliki jarak distribusi pemenuhan kebutuhan beras paling kecil. Aceh, Sumatera Utara, Sumatera Barat, Sumatera Selatan, Bengkulu, 
Lampung, DKI Jakarta, Jawa Barat, Jawa Tengah, D.I Yokyakarta, Jawa Timur, Banten, Bali, Nusa Tenggara Barat, Kalimantan Timur, Sulawesi Tengah, Sulawesi tenggara, dan Sulawesi Barat. Informasi spasial kategori wilayah berdasarkan jarak pemenuhan kebutuhan beras dapat dilihat pada Gambar 2.

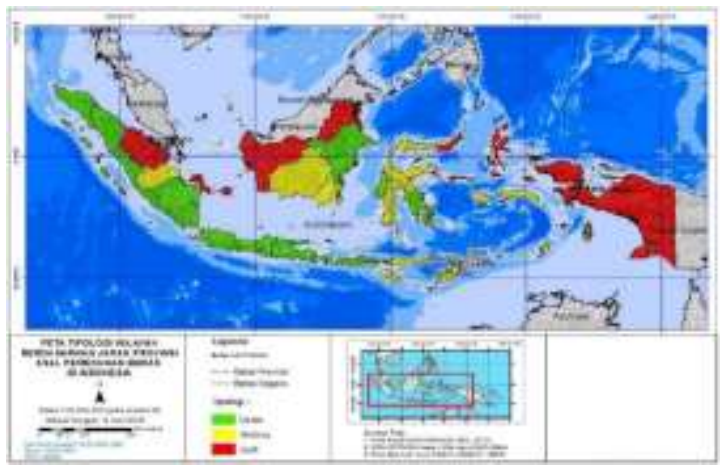

Gambar 2. Kategori Wilayah

Berdasarkan Jarak Provinsi Asal Pemenuhan Beras

Sumber: Analisis Data Primer (2019)

Perbedaan jarak pemenuhan beras masing-masing provinsi ini selain disebabkan oleh perbedaan kelengkapan infrastruktur yang tersedia, juga disebabkan oleh kondisi alam yang kurang mendukung, seperti faktor bencana alam.(Sukardi et al., 2020) Selain itu faktor budaya masyarakat juga dapat mengakibatkan perbedaan kemampuan masing-masing provinsi dalam memenuhi kebutuhan beras di wilayahnya. Hal ini sesuai dengan pendapat (Grigg, 1974) yang menyebutkan bahwa kondisi demografi dan budaya masyarakat mampu mengubah populasi agricultur di suatu wilayah. Dalam kondisi tertentu tidak adanya penerus dalam usaha pertanian oleh generasi selanjutnya dapat menyebabkan menurunnya luas lahan pertanian, termasuk sawah. Kondisi ini dapat mengakibatkan semakin berkurang pula produksi beras di suatu wilayah, sehingga saat hasil produksi lokal tidak mampu memenuhi kebutuhan maka akan mendorong wilayah tersebut untuk mendatangkan beras dari provinsi lainnya.

\section{Kategori Wilayah Berdasarkan Analisis Food Miles}

Secara umum terdapat enam kategori food miles dalam penelitian ini, dimana masing-masing kategori tersebut memiliki karakteristik yang berbeda-beda. Kategori I merupakan food miles dekat-surplus. Kategori ini menunjukan bahwa wilayah tersebut memiliki kondisi surplus beras dan sebagian besar asal pemenuhan berasnya berasal dari dalam provinsi. Hasil penelitian ini menunjukan bahwa kategori surplus-dekat merupakan kategori yang paling dominan, yaitu sebesar 38,24\%. Hal ini merupakan sesuatu yang wajar dimana wilayah yang surplus akan memaksimalkan kebutuhan berasnya dari wilayahnya sendiri, sehingga menyebabkan jarak pemenuhan kebutuhan berasnya lebih kecil dibandingkan dengan wilayah lainnya.

Kategori II ialah food miles sedang-surplus, dimana wilayah dalam kategori ini pada dasarnya dapat memenuhi kebutuhan beras lokal, namun mendatangkan beras dari wilayah lainnya dengan jarak yang cukup jauh. Persentase wilayah yang termasuk pada kategori ini sebesar $11,76 \%$. Kategori III ialah jauh-surplus dengan persentase sebesar 2,94\%. Persentase kategori IV (dekat-defisit) sebesar $14,70 \%$. Kategori $\vee$ (Sedang- 
Strategi Ketahanan Pangan Beras berdasarkan Pendekatan Food Miles/Armandha Redo Pratama, Sudrajat, Rika Harini, Purna Hindayani

defisit) dengan jumlah persentase $11,76 \%$, dan Kategori VI (jauh-defisit) sebesar 20,59\%. Diagram dapat dilihat pada Gambar 3.

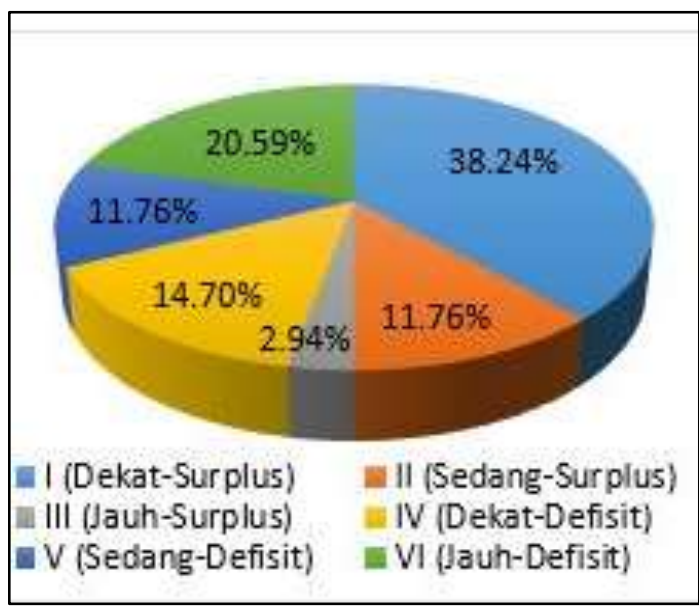

Gambar 3. Persentase kategori wilayah berdasarkan jarak pemenuhan beras Sumber: Analisis Data Primer (2019)

Pada dasarnya wilayah desifit akan mendatangkan beras dari wilayah lainnya, namun hal yang menjadi perhatian ialah dari mana beras tersebut didatangkan dan seberapa jauh jarak tempuh untuk distribusinya. Hasil penelitian menyebutkan bahwa wilayah defisit ternyata lebih besar malakukan distribusi beras dari jarak yang lebih jauh, hal ini terbukti dengan persentase kategori VI, yaitu food miles jauh defisit yang memiliki persentase terbesar dibandingkan dengan kategori wilayah dedfisit lainnya. Persentase kategori Food miles jauh-defisit sebesar $20,59 \%$, kategori dekat defisit $14,71 \%$, dan kategori sedang-defisit memiliki persentase $11,76 \%$. Informasi spasial terkait kategori wilayah berdasarkan analisis food miles dapat dilihat pada Tabel 2 dan Gambar 4.
Tabel 2. Kategori wilayah berdasarkan analisis food miles

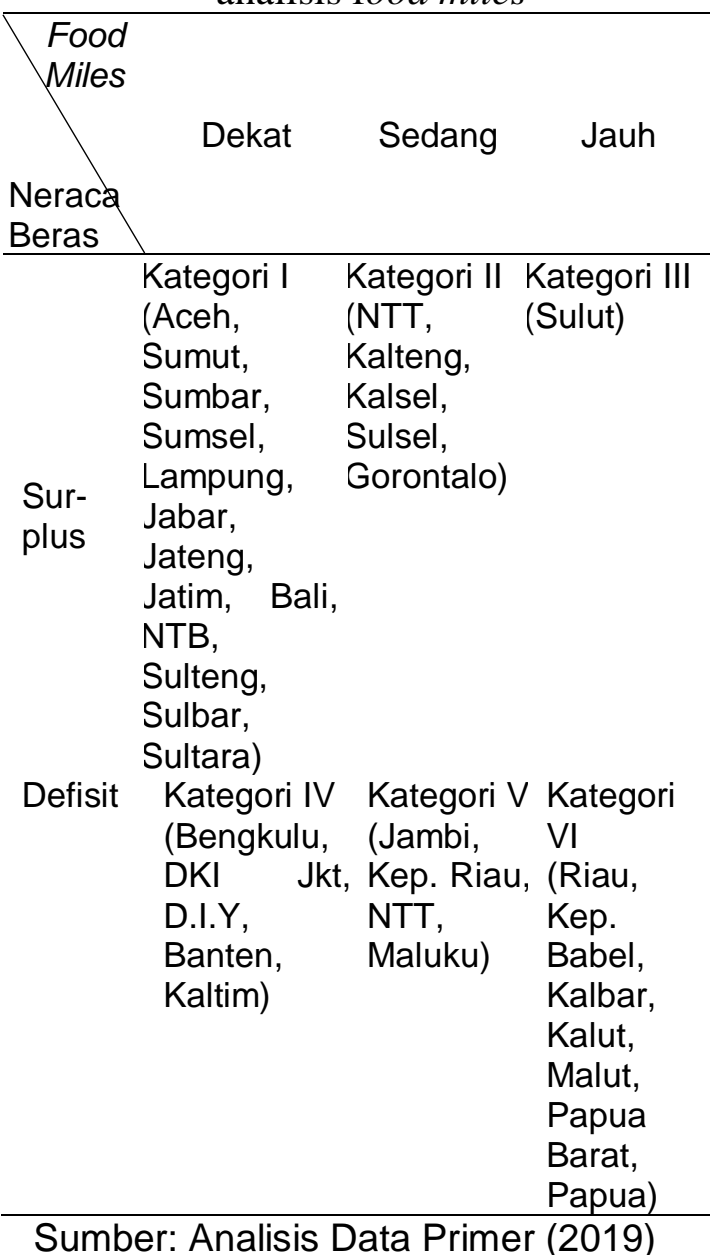

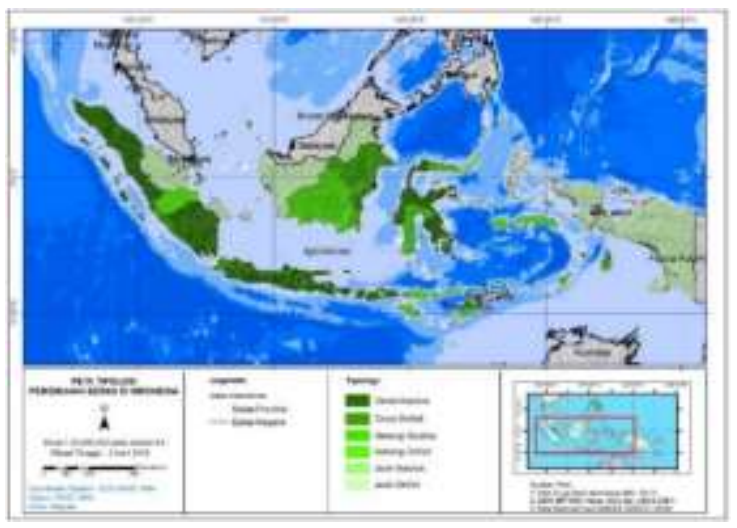

Gambar 4. Peta Kategori Pemenuhan Beras di Indonesia

Sumber: Analisis Data Primer, 2019 
Strategi Ketahanan Pangan Beras berdasarkan Pendekatan Food Miles/Armandha Redo Pratama, Sudrajat, Rika Harini, Purna Hindayani

Widodo (2003) menyebutkan bahwa besar kecilnya stok beras dipengaruhi oleh harga beras, besarnya permintaan dan penawaran, jumlah penduduk, besarnya impor dan stok sebelumnya. Berdasarkan penjelasan tersebut, terdapat satu faktor yang paling memengaruhi jumlah stok beras di suatu daerah. Faktor tersebut ialah surplus beras yang dipasarkan oleh petani. Penjualan beras oleh petani dapat dijual kepada pemerintah, distributor/pedagang ataupun kepada konsumen langsung. Sehingga disimpulkan bahwa untuk kategori jarak pemenuhan kebutuhan beras atau food miles rendah-surplus sebagian besar suplai berasal dari wilayah sendiri, hal ini dikarenakan Produksi Beras lokal mampu memenuhi kebutuhan beras lokal.

Kondisi berbeda dialami oleh Provinsi dengan kategori jarak pemenuhan kebutuhan beras rendahdefisit, dimana produksi lokal belum mampu memenuhi kebutuhan dalam provinsi. Kondisi ini mengharuskan wilayah tersebut mampu menerapkan konsep food miles yang ideal, dimana pemenuhan kebutuhan beras dalam provinsi didatangkan dari wilayah yang relatif dekat dari provinsi yang bersangkutan, sehingga hal ini akan menekan biaya distribusi yang harapannya akan mampu menekan harga jual beras di provinsi yang bersangkutan.

\section{Optimasi Jalur Distribusi Perdagangan Beras}

Analisis yang digunakan dalam optimalisasi jalur distribusi beras ialah analisis linier program melalui program lindo 6.1. Melalui metode ini tidak hanya menghasilkan jalur distribusi yang mengeluarkan biaya paling optimum. Secara umum kondisi yang ideal untuk mencapai ketahanan beras berdasarkan pendekatan food miles ialah dengan memaksimalkan produksi beras lokal secara keseluruhan untuk memenuhi kebutuhannya, sedangkan untuk provinsi yang mengalami defisit beras, dapat mendatangkan beras dari daerah sekitarnya. Hasil optimasi distribusi beras dapat dilihat pada Gambar 5 dan 6.

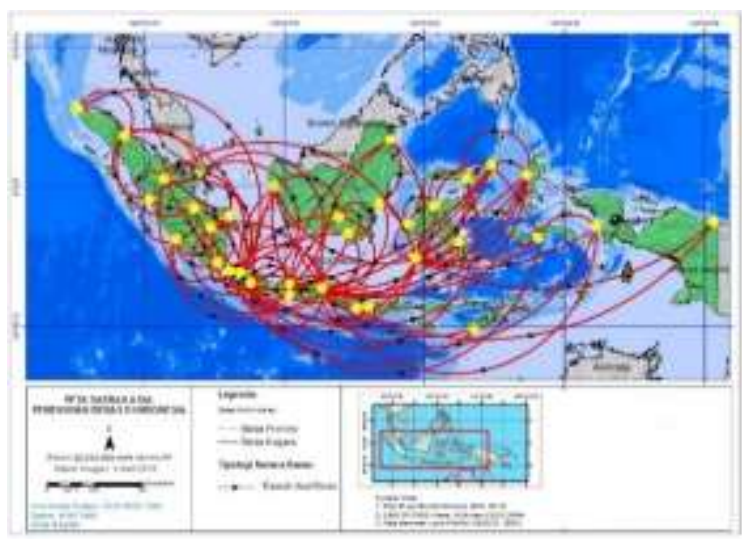

Gambar 5. Peta jalur distribusi beras sebelum optimasi

Sumber: Analisis Data Primer (2019)

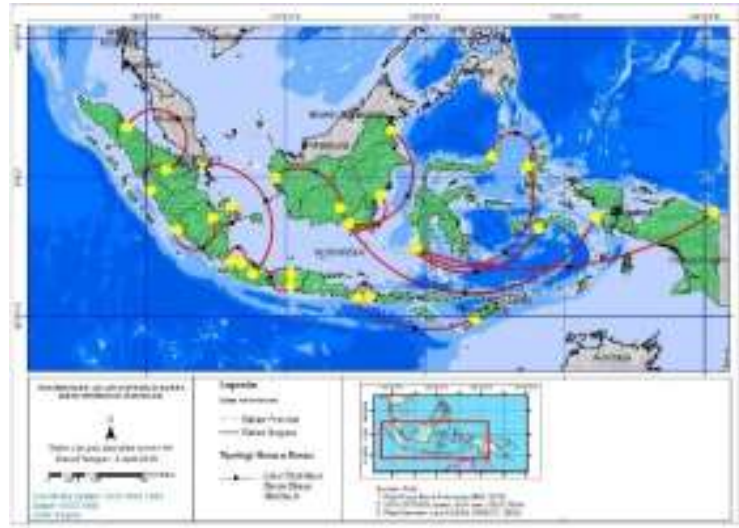

Gambar 6. Peta jalur distribusi beras setelah optimasi

Sumber: Analisis Data Primer (2019)

Berdasarkan hasil analisis hampirr seluruh rute distribusi yang direkomendasikan harus ditambahkan 
jumlah beras yang akan didistribusikan, hanya rute distribusi DKI Jakrta Banten, Jawa Barat - DKI Jakarta, Jawa Tengah - D.I Yogyakarta, NTB - Bali, dan Sulawesi Selatan - Maluku Utara yang direkomendasikan untuk mengurangi jumlah distribusinya. Pengurangan jumlah beras yang didistribusikan ini berdasarkan persamaan biaya pengiriman serta pertimbangan kendala ketersediaan dan kebutuhan pada masing-masing Provinsi. (Farahani \& Elahipanah, 2008) menyebutkan bahwa metode transportasi dan program linier dapat mengoptimalkan biaya distribusi, sehingga seluruh permintaan dapat dipenuhi.

Hasil analisis pada penelitian ini juga menunjukan bahwa hasil optimasi jaring distribusi yang lebih efektif daripada distribusi perdagangan beras pada tahun 2018. Hal ini dapat dilihat dengan membandingkan antara peta distribusi beras sebelum dioptimasi pada gambar 3 dan setelah optimasi pada gambar 4 .

Berdasarkan hal tersebut dapat disimpulkan bahwa terdapat provinsi yang harus mendatangkan dari berbagai wilayah untuk memenuhi kebutuhan beras di provinsi tersebut, namun juga terdapat provinsi yang berperan sebagai pemasok dan mendistribusikan produksi berasnya menuju provinsi lain. Salah satu provinsi yang memasok beras dari provinsi lainnya ialah Provinsi Riau. Provinsi Riau dapat memasok beras dari Provinsi Sumatera Utara dan Sumatera Barat, sedangkan Provinsi yang berperan sebagai supplier beras bagi provinsi lainnya ialah Provinsi Sumatera Selatan, Provinsi Jawa Barat, Provinsi Kalimantan Selatan, Provinsi
Kalimantan Tengah, dan Provinsi Sulawesi Selatan. Kelemahan metode transportasi linier program dalam penelitian ini ialah tidak memperhatikan faktor pembatas selain ketersediaan dan kebutuhan masing-masing provinsi. Faktor-faktor lain tersebut seperti perilaku pedagang, kualitas beras, kepemilikan aset transportasi pedagang dan lain lain yang dapat membentuk perilaku perdagangan beras.

\section{Strategi Ketahanan Beras berdasarkan Pendekatan Food Miles}

Penentuan kategori wilayah berdasarkan pendekatan food miles pada komoditas beras dapat memudahkan pemilihan alternatif strategi yang dapat diterapkan. Strategistrategi ini akan lebih berpeluang berhasil, sebab pendekatan yang digunakan ialah spesifik sesuai karakteristik wilayah yang berbedabeda. Menurut (Muta'ali, 2015) pengambilan keputusan merupakan kegiatan yang pasti dilakukan dalam perencanaan pengembangan wilayah, untuk itu keputusan atau kebijakan yang dipilih seharusnya dilakukan dengan cepat, tepat dan efisien. Hal ini bertujuan agar dapat menemukan dan menyelesaikan masalah pembangunan di suatu wilayah dengan cepat, tepat dan menggunakan energi yang optimal.

Prinsip interpretasi strategi yang dibangun ialah bagaimana wilayah dengan kondisi ketersediaan beras surplus mampu mengambil keuntungan dari peluang yang ada, yaitu terpenuhinya kebutuhan beras dari dalam wilayah tersebut, serta menyalurkan kelebihan volume beras menuju wilayah disekitarnya, serta bagaimana suatu wilayah dengan 
kondisi defisit beras mampu memenuhi kebutuhan beras diwilayahnya dengan kondisi biaya distribusi yang optimum.

Selanjutnya dapat dirumuskan strategi-strategi umum yang dapat dilakukan untuk menyelesaikan masalah ketersediaan dan kebutuhan beras berdasarkan kategori yang telah ditentukan. Analisis yang digunakan ialah analisis SWOT. Masing-masing komponen pada penelitian ini yaitu, strenght merupakan kondisi surplus beras, weakness merupakan kondisi defisit beras, sedangkan opportunities dan threats merupakan jarak pemenuhan kebutuhan beras suatu wilayah yaitu dekat hingga jauh.

Berdasarkan asumsi dan prinsip interpretasi tersebut, diperoleh beberapa alternatif strategi dari kategori wilayah berdasarkan ketersediaan dan kebutuhan beras di Indonesia. Strategi tersebut dapat dilihat pada Tabel 3.

1) Kategori I (surplus, dekat): strategi optimal, distributif, konservatif

Kategori ini menandakan posisi wilayah yang kuat, dimana ketersediaan berasnya berlebih dan sumber beras berasal dari dalam wilayah itu sendiri, serta minim intervensi wilayah lain dalam hal pemenuhan kebutuhan beras. Strategi yang dapat dilakukan pada kategori 1 ini diantaranya ialah memanfaatkan ketersediaan beras di wilayah secara maksimal untuk memenuhi kebutuhan lokal, mendistribusikan sebagian produksinya menuju wilayah defisit di sekitar, dan mempertahankan produkdivitas hasil sawah.
2) Kategori II (surplus, sedang): strategi optimal, defensif, konservatif

Kategori ini menandakan posisi wilayah yang cukup kuat, dimana ketersediaan berasnya berlebih dan sebagian besar sumber beras berasal dari dalam wilayah itu sendiri, serta terdapat intervensi sedang dari wilayah lain dalam hal pemenuhan kebutuhan beras. Strategi yang dapat dilakukan pada kategori II ini diantaranya yaitu memanfaatkan ketersediaan beras di wilayah secara maksimal untuk memenuhi kebutuhan lokal, serta mempertahankan produktivitas hasil sawah.

3) Kategori III (Surplus, jauh): strategi optimal, protektif, konservatif

Kategori ini menandakan posisi wilayah yang kuat dalam ketersediaan beras, namun ketersediaan tersebut tidak berasal dari wilayah itu sendiri, serta terdapat intervensi yang besar dari wilayah lain dalam hal pemenuhan kebutuhan beras. Strategi yang dapat dilakukan pada kategori III ini diantaranya ialah memanfaatkan ketersediaan beras di wilayah secara maksimal untuk memenuhi kebutuhan lokal, menjaga masuknya distribusi beras dari wilayah lain, dan mempertahankan produktivitas hasil sawah. 
Tabel 2. Strategi ketahanan beras

Berdasarkan Pendekatan food miles

\begin{tabular}{|c|c|c|c|}
\hline $\begin{array}{l}\text { Food } \\
\text { Miles }\end{array}$ & Dekat & Sedang & Jauh \\
\hline $\begin{array}{l}\text { Neraca } \\
\text { Beras }\end{array}$ & & & \\
\hline Surplus & $\begin{array}{l}\text { Kategori } \\
\text { Optimal, } \\
\text { Distribu- } \\
\text { tif, } \\
\text { Konser- } \\
\text { vatif }\end{array}$ & $\begin{array}{l}\text { Kategori II } \\
\text { Optimal, } \\
\text { Defensif, } \\
\text { Konservatif }\end{array}$ & $\begin{array}{l}\text { Kategori III } \\
\text { Optimal, } \\
\text { Protektif, } \\
\text { Konservatif }\end{array}$ \\
\hline Defisit & $\begin{array}{l}\text { Kategori } \\
\text { IV } \\
\text { Optimal, } \\
\text { Kolektif, } \\
\text { Revolutif }\end{array}$ & $\begin{array}{c}\text { Kategori V } \\
\text { Optimal, } \\
\text { Kolektif, } \\
\text { Progresif }\end{array}$ & $\begin{array}{c}\text { Kategori VI } \\
\text { Optimal, } \\
\text { Kolektif, } \\
\text { Variatiff }\end{array}$ \\
\hline
\end{tabular}

4) Kategori IV (defisit, dekat): strategi optimal, kolektif, revolutif

Kategori ini menandakan posisi wilayah yang lemah dalam ketersediaan beras dan melakukan distribusi beras dari wilayah lain untuk memenuhi kebutuhan berasnya, namun dengan jarak pemehunan beras yang dekat, artinya jumlah wilayah yang mensuplai beras menuju wilayah pada tipe ini sedikit, namun dapat memenuhi kebutuhan berasnya, sehingga tingkat intervensi wilayah lain dalam hal pemenuhan kebutuhan beras diwilayah ini ialah kecil. Strategi yang dapat dilakukan pada kategori IV ini diantaranya ialah memanfaatkan ketersediaan beras di wilayah secara maksimal untuk memenuhi kebutuhan lokal, mempertahankan memenuhi kebutuhan beras dari wilayah surplus yang dekat, dan meningkatkan Produksi Beras dengan rekayasa teknologi.
5) Kategori $V$ (defisit, sedang: strategi optimal, kolektif, progresif

Kategori ini menandakan posisi wilayah yang lemah dalam ketersediaan beras dan melakukan distribusi beras dari wilayah lain untuk memenuhi kebutuhan berasnya, dengan jarak pemehunan beras yang cukup jauh, artinya jumlah wilayah yang mensuplai beras menuju wilayah pada tipe ini cukup banyak, sehingga tingkat intervensi wilayah lain dalam hal pemenuhan kebutuhan beras diwilayah ini ialah cukup besar. Strategi yang dapat dilakukan pada kategori $\mathrm{V}$ ini diantaranya ialah memanfaatkan ketersediaan beras di wilayah secara maksimal untuk memenuhi kebutuhan lokal, memenuhi kebutuhan beras dari wilayah surplus yang dekat, dan meningkatkan Produksi Beras dengan mempertahankan lahan sawah.

6) Kategori VI (defisit, jauh): strategi optimal, kolektif, variatif

Kategori ini menandakan posisi wilayah yang lemah dalam ketersediaan beras dan melakukan distribusi beras dari wilayah lain untuk memenuhi kebutuhan berasnya, dengan jarak pemehunan beras yang jauh, artinya jumlah wilayah yang mensuplai beras menuju wilayah pada tipe ini banyak, sehingga tingkat intervensi wilayah lain dalam hal pemenuhan kebutuhan beras diwilayah ini ialah besar. Strategi yang dapat dilakukan pada kategori $\mathrm{VI}$ ini diantaranya ialah memanfaatkan ketersediaan beras di wilayah secara maksimal untuk memenuhi kebutuhan lokal, 
memenuhi kebutuhan beras dari wilayah surplus yang dekat, dan menambah alternatif makanan pokok lainnya.

\section{Penutup}

Terdapat enam kategori wilayah berdasarkan kegiatan distribusi perdagangan berasnya. Kategori tersebut berdasarkan jarak asal pemenuhan kebutuhan beras di Indonesia, yaitu kategori food miles dekat - surplus, dekat - defisit, sedang surplus, sedang - defisit, dan tinggi defisit.

Seluruh Provinsi di Pulau Jawa memiliki kategori food miles dekat, sedangkan kategori food miles sedang sebarannya bervariasi dari Pulau Sumatera hingga Pulau Sulawesi. Selanjutnya Provinsi dengan kategori food miles jauh lebih didominasi oleh Provinsi di Indonesia bagian timur seperti Provinsi Papua, Provinsi Papua Barat, dan Provinsi Maluku. Seluruh kategori ini memilki strategi pengembangan yang berbeda-beda, kategori satu menerapkan strategi distributif, kategori dua strategi defensif, kategori tiga strategi protektif, kategori empat srategi revolutif, kategori lima strategi progresif, kategori enam strategi variatif.

\section{Daftar Pustaka}

Badan Pusat Statistik. (2016). Distribusi Perdagangan Komoditas Beras.

Brief F. P. (2006). Food security Food security. FAO Agriculture and Development Economics Division, 2.

Cushing, N. (2020). Counting the food miles of sugar in early colonial Australia.

Https://Doi.Org/10.1080/07409710
$.2020 .1783818, \quad 28(3), \quad$ 195-214. https://doi.org/10.1080/07409710. 2020.1783818

Edward, F. P. D. (2002). Supply Chain Strategy: The Logistics of Supply Chain Management. https://www.accessengineeringlibr ary.com/content/book/9780071375 993

Farahani, R. Z., \& Elahipanah, M. (2008). A genetic algorithm to optimize the total cost and service level for just-in-time distribution in a supply chain. International Journal of Production Economics, 111(2), 229-243.

https://doi.org/10.1016/J.IJPE.200 6.11 .028

Grigg, D. B. (1974). Agricultural Populations And Economic Development. Tijdschrift Voor Economische En Sociale Geografie, 65(6), 414-420. https://doi.org/10.1111/J.14679663.1974.TB01248.X

Herdiawan, D. (2015). Industri maritim dan peranannya terhadap distribusi pangan di wilayah terpencil dalam rangka memperkokoh ketahanan pangan nasional. http://elibrary.sb.ipb.ac.id

Karo, N. (2016). Analisis optimasi distribusi beras bulog di Provinsi Jawa Barat. https://repository.mercubuana.ac.i d/38993/

Kemp, K., Insch, A., Holdsworth, D. K., \& Knight, J. G. (2010). Food miles: Do UK consumers actually care? Food Policy, 35(6), 504-513. https://doi.org/10.1016/J.FOODPO L.2010.05.011

Lawlis, T., Islam, W., \& Upton, P. (2018). Achieving the four dimensions of food security for resettled refugees in Australia: A systematic review. Nutrition \& Dietetics, 75(2), 182192. https://doi.org/10.1111/17470080.12402

Lin, Z., \& He, W. (2020). The Multiple 
Dimensions of Food Security of China in the Context of Labor Costs Rising. IEIS2019, 693-703. https://doi.org/10.1007/978-98115-5660-9 52

Lopez, R., \& Khanal, B. (2020). Got Local? The Impact of Food Miles on the Demand for Milk. 1020636, $1-15$.

Muta'ali, L. (2015). Teknik analisis regional untuk perencanaan (347th ed.). Badan Penerbit Fakultas Geografi Universitas Gadjah Mada.

Nashwari, I. P. (2020). Optimalisasi ketersediaan data dukung penyusunan kebijakan distribusi pangan melalui toko tani Indonesia Center (TTIC). http://repository.pertanian.go.id/bit stream/handle/123456789/10087/I nti P..pdf?sequence=2

Pramono, S., \& Changming, L. (2019). Global Maritime Fulcrum and the New Eurasia: Opportunity and Challenge for Indonesia. 140(ISCoGI 2017), 25-28. https://doi.org/10.2991/iscogi17.2019.7

Sukardi, N. I., Canra, D., Konoras, A., Ridho, M., Pascasarjana, P., Khairun, U., Pascasarjana, P., \& Khairun, U. (2020). Journal of Science and Engineering Elites. 05(1), 33-37. www. ElitesJournal.ir

Sulaiman, S. (2019). Ekonomi Indonesia antara Amanat Undang-undang Dasar 1945 dan Realita. Jurnal Syariah, 7(2), 1-17. http://ejournal.fiaiunisi.ac.id/index. php/syariah/article/view/257

Suratha, I. K. (2017). Krisis Petani Berdampak Pada Ketahanan Pangan Di Indonesia. Media Komunikasi Geografi, 16(1). https://doi.org/10.23887/MKG.V16I 1.10172

Suryana, A. (2014). Menuju Ketahanan Pangan Indonesia Berkelanjutan 2025: Tantangan dan
Penanganannya. Forum Penelitian Agro Ekonomi, 32(2), 123-135. https://doi.org/10.21082/FAE.V32 N2.2014.123-135

Verstappen, H. T. (2013). Garis besar geomorfologi Indonesia: studi kasus dalam geomorfologi tropis wilayah tektogen: dilengkapi dengan peta geomorfologi skala 1: 5.000. 000. Gadjah Mada University Press.

Widodo, S. (2003). Pengaruh globalisasi terhadap ketahanan pangan nasional. Agro Ekonomi, 10(2003).

Wong, J. (2019). Are food miles important? New Scientist, 243(3241), 24. https://doi.org/10.1016/S02624079(19)31428-9

World Bank. (2019). World development report 2019: The changing nature of work. 